\title{
Forming the image of Other: Religion in the Geopolitical Maps Around Jungar and Kalmyk Khanates
}

\author{
Baatr Kitinov \\ Institute of Oriental Studies Russian Academy of Sciences \\ Moscow, Russia, Rozhdestvenka str., 12
}

The first third of XVIII century was very important for Kalmyks and Jungars. The political affairs, where Kalmyks, Russians, Jungars and Manchus as well as the external issues have been communicated, had been closely related with the religious matters, led to intensification of regional political processes. In Kalmyk khanate the Buddhist affairs were under the supervision of the famous Shakur Lama, and it was during his rule when the Islamic issue had had some importance, because it had been closely related with the plan to establish the Kalmyk-Crimean khanate (perhaps, initially the Ottomans' idea). In Jungaria the situation was even more complex due to the policy of Qing, when the leaders of this khanate were accused in conversion to Islam. The rare word "Thomkar" from Russian archival materials illustrates very special skill of Qing officials - it was "created" for Jungars to define them as being "converted" to Islam. The meaning of all these events allow to suppose, that religion at the time under consideration became the state tool for implementation of the virtual geopolitical maps to change the "usual" image of someone into "necessary" "enemy face".

Keywords: Thomkar, Buddhism, Islam, Kalmyks, Dzungars, Anjjathan-lama

\section{Introduction}

In 1715 the Kalmyk Ayuka-khan had met at his urga (court) the famous Qing delegation headed by Tulishen, the prominent Qing politician. This visit should be considered within Ayuka's policy to strengthen the relationship with the foreign powers. Also quite intensive were the relations of Kalmyk khanate with Persia, Turkey and the Central Asian khanates (first of all, with the Jungarian khanate), let alone the ties with St. Petersburg. Jungars, who controlled the Eastern Turkestan and some parts of Kazakh steppe, in 1717-1720 occupied Tibet (mainly U province with Lhasa), and this event again actualized the religious matter in the Qing policy towards Jungaria and Tibet.

(C) Kitinov Baatr, 2019. 


\section{The investigation of the issue}

In spring of 1719, the famous Shakur Lama, originally from Volga Kalmyks, arrived to Ayuka. Lama spent in Lhasa more than 20 years, and seems, he was very close person to both Six Dalai Lamas, Tsanyan Gyatso (Tib. blo bzang rin chen tshangs dbyangs rgya mtsho, Dalai-lama in 1697-1706) and Ngawang Yeshe Gyatso (Tib. ngag dbang ye shes rgya mtsho, Dalai-lama in 1707-1717); also he was the Head lama of Shakhor monastic college - one of the seven monastic colleges in the Drepung monastery: Gomang (Sgo mang), Loselling (Blo gsal gling), Deyang (Bde dbyangs), Shakhor (Shag skor), Gyelwa (Rgyal ba), Dulwa ('Dul ba), and Ngagpa (Sngags pa)). Being back, Shakur Lama became the spiritual leader of the Kalmyk Khanate [13].

Shakur Lama had been troubled by the possible grow of influence of Islam among Kalmyks (1). The fact was that, from the time of Central Asian period of the Kalmyk history, there were dependent Muslims among them who eventually married Kalmyk women. Their descendants were, as a rule, the Muslims by faith. These Kalmyks were known as Tomuts [1. L. 9; 7. P. 99; 15]. They have had enjoyed considerable power and influence at Donduk Ombo's court (one of Ayuka's descendants) even before he became a Khan of Kalmyks in November 14, 1735. Shakur Lama faced with the Muslims surrounding Donduk Ombo, and he was against their influence on the Kalmyk affairs [7. P. 196]. Besides, in 1721, Donduk Ombo had married Dzhan, a daughter of the Kabardinian khan, a Muslim, and abandoned his former wife Sol, who was originally from the Kalmyk Khoshud nation (2).

Moreover, after Ayuka's death, in $1720^{\text {th }}$, Donduk Ombo was involved into the plan to organize the united Kalmyk-Crimean independent state [4. L. 197; 14]. One of the sources of this unusual idea lied in the issue of some Muslim nations (Jembuluks, Edisans), who were accepted by both Kalmyks and the Kuban sultan Bakhty-Girey as their dependent people. Bakhty-Girey, who was a son of Crimean Khan Devlet-Girey, had planned to join his lands and people of Kuban region with the Crimean ones, and so he needed the military support of Kalmyks.

It was assumed by some Kalmyk leaders, that the future united state would occupy the territory of Crimea and Kuban region, or along the Volga river [4. L. 197-198]. The religious matter of the future state was not discussed by Kalmyks and Bakhty-Girey. Donduk Dashi, the influential Kalmyk leader, who would be appointed as the Kalmyk Khan after death of Donduk Ombo, believed, that the Kuban Tatars would stay under Kalmyk supervision [4. L. 197].

Russian-Turkish relations have had the long history, which have been marked by the numerous wars and conflicts. For instance, there were two RussiaTurkish wars in XVII century, and four - in XVIII century. One of the important wars happened in 1735-1739, and it also was connected with the situation, formed in the discussing area, when Crimean and other Tatar nations of the region, as well as Kalmyks, were involved in those battles and war events. It is possible to assume, that it was idea from the Ottoman politicians, who were interested in 
worse situation in South Russian borders by creating the Muslim-Buddhist united state under the protection of Istanbul.

Finding himself in troubles, Shakur Lama tried to get support from Tibet. At that time in Tibet clashes between supporters of the different schools, quarrels between the Kalons (bka' blon) [ministers of the Tibetan government], gave a way to power to Pholhanas Sodnam Topgye (pho lha ba bsod nams stobs rgyal, r. 1723-1747), who in November of 1728, forced the young Seventh Dalai Lama Lobsan Kalsan Gyatso (blo bzang bskal bzang rgya mtsho (Dalai-lama in 17201757) to exile for more than seven years. It was time when the Kalmyk leaders decided to send a delegation to Dalai-lama.

The specially formed delegation, consisted of 41 persons, lamas and laymen, went to the East in December of 1729 . We have no record of when the envoys met with the Dalai-lama, but it is known that they met at Gartar, in Kham province, where the new monastery was built for the exiled religious leader. Delegation before their travel received a number of requests from Shakur Lama. Thus, Shakur Lama appealed to lamas of Kalmyk origin, who lived in Tibet or Beijing, to return to the Kalmyk Khanate [5. L. 6, 69].

Also he looked for information on Tsandan Jowo, a sandalwood statue of the Buddha, which, as it was believed, had been made during the life of the Buddha and was later kept in various parts of India, then in China (brought there by the famous Kumarajiva (344-413). In XVIII century the statue was kept in Beijing Zandan-sy temple, under the supervision of the Kalmyk and other lamas. Perhaps, the appearance of Tsandan Jowo in the Kalmyk lands was conceived by Shakur Lama as a fundamental step in revitalizing the Buddhist faith and strengthening the united Kalmyk state. He also sought to swiftly increase the number of his supporters by the return of the Kalmyk lamas from the Tibetan monasteries to the Khanate.

The Russian government have monitored the ethnic and religious situations in the Kalmyk Khanate and in neighboring territories. Thus, after Donduk Ombo's death in 1741, the government "couldn't find it possible to satisfy the request of Dzhan [to appoint her son Randula to be the Kalmyk khan], reasonably arguing that as a Mohammedan by faith, Dzhan 'will always be on the side of the Kabardians"” [16. P. 48], i.e. could manage pro-Turkey or anti-Russian policy.

Shakur Lama tried to create a Buddhist state in Kalmyk lands, based on principle of "two laws". He understood the preservation of Buddhism among the Kalmyk people as his main goal. He also strove to strengthen Buddhism among Kalmyks, seeing it as their identity marker. Besides, in order to diminish the influence of such religions, like Russian Orthodox and Islam on the Kalmyks, he, as it is seen from the documents, intended to build a palace (or a temple) in which he was going to place the statue of Tsandan Jowo [2. L. 134].

There are a lot of studies on the significant influence of religion (Buddhism) on Qing dynasty politics, especially in relations with Jungaria and the Khosuts of Kukunor region (so-called Kukunorians) [18; 6; 9]. Obviously, religion and its in- 
stitutions had been strongly influenced by the Manchu emperor and officials. All this happened during the reign of Emperor Kangxi (r. 1662-1722), who actually did not hide his utilitarian attitude towards Buddhism, which, in general, was characteristic matter for his successor Yunjen (r. 1722-1735) and other Qing rulers. But an special issue took the place in their religious politics - the Qing accused the Jungar rulers in convertion to Islam; this policy began with Galdan Boshoktu-khan (r. 1671-1697), but during time of Tsevan-Rabdan (r. 1697-1727) and especially Galdan-Tseren (r. 1727-1745), his son, the Islamic theme had been stretched to attention of the Russian authority.

Russian archival documents indicate that this issue became the matter in the diplomatic correspondence between Beijing and St. Petersburg in beginning of 1730th. Jungarian leader Galdan-Tseren, like his father, Tsevan-Rabdan, had been called by Manchu officials as "Thomkar" (Rus. Тхомкар): "Thomkar Galdan Cheren, father and son, they're making bad deeds from generation to generation, and all neighboring states had been offended [by them]"" [3. L. 140]; and all Jungars are also marked with the same word: "... an army has been sent to stop Thomkars..."2 [3. L. 140].

The document provides this word only in Russian (“тхомкар"), without any explanation; none of the researchers had previously paid attention to this word, let alone the meaning of it. Meanwhile, the study of both its meaning and features of use, characterizes a special situational context: in our opinion, it is most likely to understand it (from Tibetan) as "falling into white" ('thom dkar), in other words "becoming heretics" or "converted to Islam".

I have consulted on this word with the famous Tibetologist Jose Cabezon of the University of California in Santa Barbara, who noted that the meaning of this word is close to the meaning "gone to Islam". I fully agree with him, and suppose that "thomkar" is a derivative of 'thom pa (among a number of meanings "stupefied"), and dkar wa (white) - " "thom dkar": "stupefied by white", "fallen into white", which should be understood either for heretics (the usual definition of the Mongol imperial period, for instance, for assassins or followers of Mani teaching), or Muslims (who became Muslims): in the texts of Kālacakra Tantra, Tibetans refer to Muslims as kla klo ("those with darked consciousness", from Sanskrit Mleccha (Tib. mustegs pa), but the most commonly accepted definition for them (Muslims) is "white hats" (mgo dkar) [8. P. 63-64]. Another interpretation is also possible: 'thom in the meaning of "being stupid", and kar in the meaning "great pain", "suffering"; it turns out "thom kar" "those who are stupid", "fools [who cause] great suffering". Definitely, this word need further investigation.

The use of the Tibetan word in diplomatic correspondence between the Manchus and the Russian side is a rare case, which, apparently, should be under-

\footnotetext{
1 «Тхомкар Галдан Черен отец и сын, от рода в род худо поступают, и всем окрестным государствам обиды чинят» (in Russian).

2 «...для отвращения тхомкар войско послано...» (in Russian)
} 
stood as an indicator of its active use in correspondence / communication with those who had been included in the sphere of Tibetan Buddhist culture: Tibetans, Mongols, and Jungars. Consequently, the accusation of the Jungar leaders, starting with Galdan, of "going away" to Islam (in such a simple way, Qing diplomacy substantiated its point of view on the reasons for the Tibetan policies of the Jungars and the need for their punishment for "harming" the Buddha's teaching) was a deliberately designed mechanism that launched the obstruction process from other Mongolian peoples, primarily Oirats and Kalmyks (3).

Thus, the newfound (created) frontiers of the religious content of society (accusation in conversion into Islam, in robbery of the Buddhist temples in Lhasa, etc.) a priori form a kind of virtual regional situation that is supposed to materialize, i.e. to make weak the spirit of people (Jungars). In some cases, this fictional "mental map", which does not coincide with realities, leads first to implicit and then to real losses for a "accused" local people, up to complete crash of their polity. Such activities, at least, could be so "useful" for outer powerful states, because it made possible to gradual forming of the necessary degree of the peoples' compliance, its readiness for future changes, although they (changes, obstacles) could have been avoided or overcome.

\section{Conclusion}

At the first third of XVIII century, religion and politics have been the important issues for Kalmyks and Jungars. At that time, Buddhism among the them was closely intertwined with the religious situation in Southern Russian regions, and with political situation in Tibet, and especially in Beijing, where the Qing rulers adopted religion mainly as the means of the politics. The political processes of the 1720s and 1730s in Tibet and among the Kalmyks and Jungars marked the beginning of a further crisis in these regions, where the influence of the Qing and Russian authorities over these territories and nations began to rise, and religion would become the part of the state structures.

\section{NOTES}

[1] The relationship of Buddhism and Islam in the Kalmyk (Oirat) society is very interesting issue, which can explain some important matters in the Oirat and Kalmyk religious history. See, for instance: [10. P. 197]. As for Islamic issues in relations to Tibet and Buddhist affairs, see: [11; 17].

[2] Khoshut Oirat nation had played an outstanding role in strengthening Oirat-Tibetan relations, due to establishment of the Dalai-lama as the spiritual and secular leader of Tibet in 1642 by their military support [12].

[3] But as for Kalmyks, Manchu used Buddhism as tool to influence on them - for instance, famous Lauzan Dzhalchin, who made a lot to make Kalmyks to go back to Jungaria in 1771, is known in history as head of Kalmyk sangha. There is nothing known in him. I do believe, that actually he was no one but "incarnation" of famous Anjjathan-lama (at that time known as Lobsan Gyaltsen). Some results of the study of the story of this person I'm going to present in the nearest future. 


\section{REFERENCES}

[1] Archive of the Foreign Policy of the Russian Empire (AFPRE). Fund "The Kalmyk files". List 119/1. File 23. 1745-1746.

[2] Archive of the Foreign Policy of the Russian Empire (AFPRE). Fund "The Kalmyk files". List 119/1. File 18. 1732-1735.

[3] Archive of the Foreign Policy of the Russian Empire (AFPRE). Fund 62. List 62/1. 1732. File 11.

[4] The National Archive of Kalmyk Republic (NAKR). Fund R-145. The personal Fund of N.N. Palmov. File 199. P. 197.

[5] The National Archive of Kalmyk Republic (NAKR). Fund 36. Consisting on the Kalmyk affairs under the Astrakhan governor. File 63. P. 6, 69.

[6] Ahmad, Zahiruddin. Sino-Tibetan relations in the seventeenth century (Roma, Istituto Italiano per il Medio ed Estremo Oriente) Serie Orientale, 1970. 345 p.

[7] Bakunin V.M. Description of the Kalmyk peoples, and especially of them of Torgout peoples, and the deeds of their khans and owners. Written in 1761. Elista: Kalmyk Book Publishing House, 1995. 153 p.

[8] Berzin A. Acceptance of Kalachakra Initiation. SPb .: Nartang, 2002. 335 p.

[9] Borjigidai Uyunbilig. The Hoshuud Polity in Khökhnuur (Kokonor) // Inner Asia. 2002. Vol. 4, no. 2. Pp. 181-195.

[10] Elverskog J. Buddhism and Islam on the Silk Road. University of Pennsylvania Press, 2010. 340 p.

[11] Islam and Tibet: Interactions Along the Musk Routes. Ed. Anna Akasoy, Charles Burnett, Ronit Yoeli-Tlalim. Ashgate, 2011. xiv+391 p.

[12] Kitinov Baatr. "Kings of Tibet": Reexamination of the Role of Khoshuts in Changing the Genghisid Principle Succession of Power to the Dalai Lama's Seal// Proceedings of the International conference "Cultural Communication and Relations between Mongolia and Tibet", vol. 1. China, Lanzhou University Press, 2017. Pp. 1-10.

[13] Kitinov Baatr. Shakur Lama: the Last Attempt to Build the Religious State// Buddhism in Mongolian History, Culture and Society. Edited by V. Wallace. Oxford University Press, 2015. Pp. 37-52.

[14] Ochirov U.B. Attempts to unite Kalmyk and Nogai tribes in the first half of the 18th century // Bulletin of the KION RAS. 2002. № 17. Pp. 77-85.

[15] Palmov Nikolai. 2007. Materials on the History of the Kalmyk People Per Stay Within Russia. Elista: Kalmyk Publishing House, 2007.

[16] Palmov Nikolai. The Essays of the History of the Kalmyk People Per Stay Within Russia Astrakhan: Kalmgosizdat, 1922. 145 p.

[17] Sela Ron. Central Asian Muslims on Tibetan Buddhism, 16th-18th Centuries // Trails of the Tibetan Tradition. Papers for Elliot Sperling. Ed. Roberto Vitali with assistance from Gedun Rabsal and Nicole Willock. Dharamshala (H.P.), India, 2014. Pp. 345-359.

[18] Soloshcheva M.A. Policy of the Qing Empire with respect to Tibet during the reign of Yunjen emperor (1723-1735). Diss ... Ph.D. SPb., 2014.

\section{ЛИТЕРАТУРА}

[1] Архив внешней политики Российской империи (АВПРИ). Ф. Калмыцкие дела. Опись 119/1. Год 1745-1746. Дело 23.

[2] Архив внешней политики Российской империи (АВПРИ). Ф. Калмыцкие дела. Опись 119/1. Год 1732-1735. Дело 18.

[3] Архив внешней политики Российской империи (АВПРИ). Ф. 62. Опись 62/1. Год 1732. Дело 11. 
[4] Национальный архив Республики Калмыкия (НАРК). Ф. Р-145. Личный фонд Н.Н. Пальмова. Дело 199.

[5] Национальный архив Республики Калмыкия (НАРК). Ф. 36. Состоящий при калмыцких делах при астраханском губернаторе. Дело 63.

[6] Ahmad, Zahiruddin. Sino-Tibetan relations in the seventeenth century (Roma, Istituto Italiano per il Medio ed Estremo Oriente) Serie Orientale, 1970. 345 p.

[7] Бакунин B.M. Описание калмыцких народов, а особливо из них торгоутского, и поступков их ханов и владельцев. Сочинение 1761 года. Элиста: Калмыцкое книжное издательство, 1995. 153 с.

[8] Берзин А. Принятие посвящения Калачакры. СПб.: Нартанг, 2002. 335 с.

[9] Borjigidai Uyunbilig. The Hoshuud Polity in Khökhnuur (Kokonor) // Inner Asia. 2002. Vol. 4, no. 2. Pp. 181-195.

[10] Elverskog J. Buddhism and Islam on the Silk Road. University of Pennsylvania Press, 2010. $340 \mathrm{p}$.

[11] Islam and Tibet: Interactions Along the Musk Routes. Ed. Anna Akasoy, Charles Burnett, Ronit Yoeli-Tlalim. Ashgate, 2011. xiv+391 p.

[12] Kitinov Baatr. "Kings of Tibet": Reexamination of the Role of Khoshuts in Changing the Genghisid Principle Succession of Power to the Dalai Lama's Seal // Proceedings of the International conference "Cultural Communication and Relations between Mongolia and Tibet", vol. 1. China, Lanzhou University Press, 2017. Pp. 1-10.

[13] Kitinov Baatr. Shakur Lama: the Last Attempt to Build the Religious State// Buddhism in Mongolian History, Culture and Society. Edited by V. Wallace. Oxford University Press, 2015. P. 37-52.

[14] Очиров У.Б. Попытки объединения калмыцких и ногайских племен в первой половине XVIII в. // Вестник КИОН РАН. 2002. № 17. С. 77-85.

[15] Пальмов Н. Материалы по истории калмыцкого народа за период пребывания в пределах России. Элиста: Калмыцкое книжное издательство, 2007.

[16] Пальмов Н.Н. Очерк истории калмыцкого народа за время его пребывания в пределах России. Астрахань: Калмгосиздат, 1922. 145 с.

[17] Sela Ron. Central Asian Muslims on Tibetan Buddhism, 16th-18th Centuries // Trails of the Tibetan Tradition. Papers for Elliot Sperling. Ed. Roberto Vitali with assistance from Gedun Rabsal and Nicole Willock. Dharamshala (H.P.), India, 2014. Pp. 345-359.

[18] Солощева M.А. Политика империи Цин в отношении Тибета в период правления императора Юнчжэна (1723-1735 гг.). Дисс... к.и.н. СПб., 2014.

Научная статья

\title{
Формируя образ «Иного»: религия в геополитических картах вокруг Джунгарского и Калмыцкого ханств
}

\author{
Б.У. Китинов \\ К.и.н., доцент, ст. научный сотрудник \\ Отдел истории Востока \\ Институт востоковедения РАН \\ ул. Рождественка, 12, Москва, Россия, 107031
}

Первая треть XVIII века была очень важна для калмыков и джунгаров. Политические вопросы, по которым шли контакты между калмыками, русскими, джунгарами и маньчжурами, а также внешнее взаимодействие были тесно сопряжены с религиозными 
моментами, что вело к интенсификации региональных политических процессов. В калмыцком ханстве буддийские дела находились под контролем знаменитого Шакурламы, и именно во время его правления исламская проблема стала иметь определенное значение, поскольку она была тесно связана с планом создания Калмыцко-крымского ханства (вероятно, изначально оттоманской идеи). В Джунгарии ситуация была еще более сложной из-за политики Цин, когда лидеры этого ханства были обвинены в конвертации в ислам. Редкое слово «тхомкар» из российских архивных материалов иллюстрирует особого рода навык цинских чиновников: оно было придумано для обозначения джунгаров, обвиняемых в «обращении» в ислам. Смысл событий позволяет предположить, что религия в рассматриваемый период стала государственным инструментом для реализации виртуальных геополитических карт, превращающих «обычный» образ кого-либо в «необходимое» «лицо врага».

Ключевые слова: тхомкар, буддизм, ислам, калмыки, джунгары, Анджатан-лама

Информация об авторах / Information about the authors

Китинов Баатр Учаевич - к.и.н., доцент, старший научный сотрудник, отдел истории Востока, институт Востоковедения РАН

Kitinov Baatr - PhD, Associates Professor, Senior research fellow, Department of history of East, Institute of Oriental studies of RAS

\section{Для цитирования / For citation}

Китинов Б.У. Формируя образ «Иного»: религия в геополитических картах вокруг Джунгарского и Калмыцкого ханств // Вестник Российского университета дружбы народов. Серия: Всеобщая история. 2019. Т. 11. № 4. С. 297-304. http://dx.doi.org/ 10.22363/2312-8127-2019-11-4-297-304

Kitinov B. Forming the image of Other: Religion in the Geopolitical Maps Around Jungar and Kalmyk Khanates // RUDN Journal of World History. 2019. Vol. 11. № 4. Pp. 297-304. http://dx.doi.org/10.22363/2312-8127-2019-11-4-297-304

Рукопись поступила в редакцию / Article received: 07.12.20 